\title{
Capability of Biowaste Composite of High Density Polythene with Egg Shell and Wood Sawdust for Sorption of Heavy Metals in Industrial Waste Water
}

\author{
IBE, KA \\ Department of Chemistry, Federal University of Petroleum Resources, Effurun, P.M.B. 1221 Effurun, Delta State, Nigeria. \\ Email: ibe.kenneth@fupre.edu.ng
}

\begin{abstract}
The health hazards posed by heavy metals in water and the need to mitigate the hazards have attracted a flurry of research interests on the technologies and methods of removing them from water. The industrial waste water from a gutter within the neighbourhood of the Delta Shopping Mall in Effurun was used to test the heavy metal sorption capacity of the waste high density polythene and biowaste composites compounded by the author using a locally constructed extruder. Some of the physico - chemical properties of the waste water determined with $\mathrm{P}^{\mathrm{H}}$ Kent meter (model 7020) and Hach conductivity meter (C0150) where within WHO acceptable limits while some were not. The metal concentrations were determined using Atomic Absorption Spectrometer(Perkin Elmer Absorption Analyst 400 model) The Composite of 2:1.5:0.5 (HDPE: saw dust: egg shell) sorbed the highest concentration of the metals ( $0.168 \mathrm{mg} / \mathrm{L}, \mathrm{Fe}$; $0.072 \mathrm{mg} / \mathrm{L}, \mathrm{Ni}$ and $0.082 \mathrm{mg} / \mathrm{L}, \mathrm{Cr}$ than the other composites of 1.5: 1: 1.5 and 2:1:1 except Cd while the composite, 2:1:1 sorbed the least concentration of metals $0.061 \mathrm{mg} / \mathrm{L}, \mathrm{Fe} ; 0.044 \mathrm{mg} / \mathrm{L}, \mathrm{Ni} ; 0.071 \mathrm{mg} / \mathrm{L}, \mathrm{Cr}$ and $0.002 \mathrm{mg} / \mathrm{L}, \mathrm{Cd}$ during the first 24 hours of sorption exposure. Chromium was the most sorbed metal, 97.6\% while cadmium was the least, $20.0 \%$. There was no systematic pattern of variation for metal absorption in the next 24 hours due probably to the blocking of the pore sites during the first twenty four hours of sorption exposure. The composite, 2:1.5:0.5 exhibited a good potential as an economic heavy metal sorbent.
\end{abstract}

\section{DOI: https://dx.doi.org/10.4314/jasem.v23i1.7}

Copyright: Copyright (C) 2019 Ibe. This is an open access article distributed under the Creative Commons Attribution License (CCL), which permits unrestricted use, distribution, and reproduction in any medium, provided the original work is properly cited.

Dates: Received: 10 December 2018; Revised: 20 January 2019; Accepted 21 January 2019

Keywords: Sorption capacity, heavy metals, composites, waste water, extruder

Heavy metals are generally defined as metals with relatively high densities and atomic weights, having atomic weights between 63.5 and 200.6, and a specific gravity greater than 5.0 (Srivastavaand Majumder, 2008), which are toxic or poisonous at increased concentrations. They are also referred to as trace elements but are the metallic elements of the periodic table (Salem et al., 2000). However, the ability of water bodies to support life as well as its suitability for other uses depends on the presence of many trace metals (Ndiaye et al., 2008). Heavy metals may occur in small amounts naturally and may enter into aquatic system through leaching of rocks, airborne dust, forest fires and vegetation (Fernandez and Olalla, 2000; Nunez et al., 2003). With the rapid development of industries such as metal plating facilities, mining operations, fertilizer industries, tanneries, batteries, paper industries and pesticides, eateries etc., waste, waters laden with heavy metals are directly or indirectly discharged into the environment especially in developing countries where such waters are hardly treated before their release.

The release of high amounts of heavy metals into water bodies creates serious health issues such as skin rashes, upset stomach, ulcers, respiratory problems, weakened immune systems, kidney and liver damage, alteration of genetic material, lung cancer, miscarriage or birth defects and ultimately death (McGrath and Smith, 1990; Sadi, 2010 and Dobrzanski. et al., 2005); and environmental problems which may lead to an increased cost of waste water treatment. Other negative impacts of heavy metals include the decrease of seed germination and lipid content by cadmium and nickel; decreased enzyme activity and plant growth by chromium; the inhibition of photosynthesis by copper and mercury; and the reduction of chlorophyll production and plant growth by lead (GardeaTorresdey et al, 2005). The most common toxic heavy metals in waste water include arsenic, lead, mercury, cadmium, chromium, copper, nickel, silver, and zinc. The persistence of heavy metals in waste water is due to their non-biodegradable nature (Jern, 2006).

To prevent the negative effects of heavy metal toxicity in waste water, there is need for adequate treatment of effluents before discharge to receiving water bodies. A number of technologies have been developed over the years to remove heavy metals from water. This includes precipitation, ion exchange, reverse phase osmosis, electrochemical processes and membrane 
technology (Israel and Inam, 2014; Sulak et al., 2007; Kumar, 2006 and Han et al., 2005). However, these methods are uneconomical and inefficient, especially at metal concentrations in the range of 10 to $100 \mathrm{mg} / \mathrm{L}$ . Biosorption has been found to be economically feasible, rapid, reversible and ecologically friendly in the removal of heavy metals from aqueous solutions, especially when used in the treatment of high volumes and low concentrations of waste water containing heavy metals (Israel and Inam, 2014). In the literature, agricultural wastes such as peanut skin, onion skin maize cob, and sugar cane bagasse and coconut fibre have been successfully used as sorbents (Israel and Inam, 2014). However, waste high density poly ethylene compounded with bio-wastes (Egg shell and wood saw dust) had not been explored. Globally, micro and macro plastics are of serious concern environmentally. The earlier they are removed from the environment the better for the world community. Therefore, this work was aimed at investigating the capability of biowaste composite of high density polythene (hdpe) with egg shell and wood sawdust for sorption of heavy metals in industrial water

\section{MATERIALS AND METHODS}

Description of the Study Area: Effurun is in Uvwie Local Government area in the Delta Central geopolitical zone of Delta State of Nigeria. The popular Delta Shopping Mall is located in the central part of this town, close to Effurun Round About, four kilometers to the Federal University of Petroleum Resources, Effurun. The PTI Road wood market is located mid way between Federal University of Petroleum Resources, Effurun and Delta shopping Mall, Effurun. The sampling locations where within $5^{0}$ $34^{\prime} 21.6^{\prime \prime} \mathrm{N}, 5^{0} 46^{\prime}$ 56.2' E and $5^{\circ} 34^{\prime \prime} 23^{\prime} \mathrm{N}, 5^{\circ} 50^{\prime \prime} 38^{\prime} \mathrm{E}$.

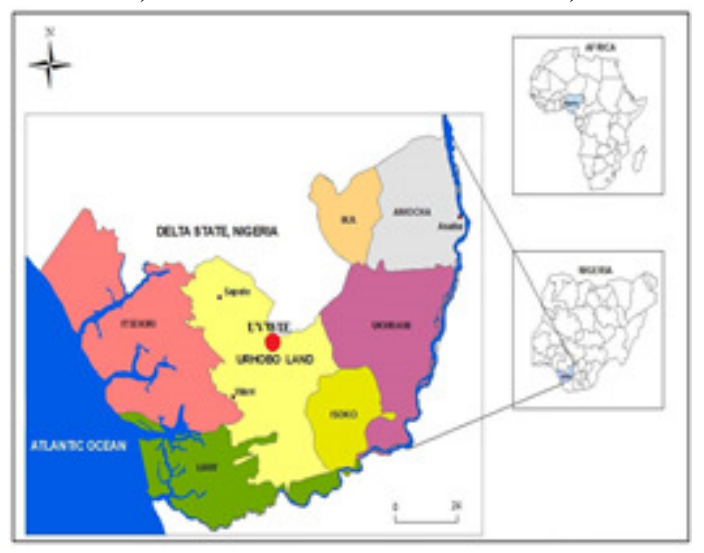

Fig 1: Map of the study area

Sampling of High density polyethylene wastes: High density polyethylene wastes were collected from waste dumps in the premises of Federal University of Petroleum Resources, Effurun, Delta State, Nigeria.
Sampling of Wood saw dusts: The wood fiber also known as wood saw dusts were collected from the PTI Road wood market, in Effurun, Delta State.

Sampling of Egg shells: The egg shell wastes were collected from Kilimanjaro eatery in Delta Shopping Mall, Effurun, Delta State.

Sampling of Waste water: The waste water was collected from a flowing gutter in front of Delta Mall at Effurun Roundabout. Prior to the sampling, a reconnaissance survey was carried out on the sampling location to avoid complications during sampling. Some in situ analytical parameters $\left(\mathrm{P}^{\mathrm{H}}\right.$ temperature, conductivity and total dissolved solids) were determined before taking the samples to the analytical laboratory of the Department of Chemistry, Federal University of Petroleum Resources, Effurun for preservation in a refrigerator pending analysis. The $\mathrm{P}^{\mathrm{H}}$ of the samples were determined using $\mathrm{P}^{\mathrm{H}}$ Kent meter (model 7020) while Hach conductivity meter (C0150) was used for conductivity and total dissolved solid.

Sample Preparation of High density polyethylene: The high density polyethylene wastes were washed with distilled water to remove sands and other substances that were associated with them. The pretreated polyethylene material was then pelletized using a locally constructed extruder machine at a pressure of $300^{\circ} \mathrm{C}$.

Sample Preparation of Wood saw dusts: The saw dusts were sun dried for two weeks to remove the associated moisture from them. They were then ground to finer particles before sieving through a 0.425 micrometer sieve.

Sample Preparation of Eggshells: The eggshells were thoroughly washed with distilled water to remove unwanted substances associated with them. They were thereafter sun dried for two weeks to remove any moisture. They were ground to finer particles before sieving through a 0.3 micrometer sieve.

Sample Preparation of Waste water: The waste water was filtered to remove pebbles, stones and other unwanted organic debris which could affect the results of the process.

Preparation of the Composite: The high density polythene, the wood saw dust and the egg shell wastes were mixed in desired ratios and loaded in the receptacle of an extruding machine when its 
temperature reading was at $400^{\circ} \mathrm{C}$. The resulting melt was channeled into molds of dimensions $30 \mathrm{~cm} \times 15 \mathrm{~cm}$ $\mathrm{x} 3 \mathrm{~cm}$ and left to cool. The prepared composites were scaled out of the molds ready for use (Ibe and Otanocha, 2017).

Heavy metal absorption process with the composites: The filtered waste water was shaken for homogeneity before been divided into three portions of ten litres each into three different containers. Samples of the water were taken from each portion for analysis of the metal contents ( $\mathrm{Fe}, \mathrm{Ni}, \mathrm{Pb}, \mathrm{Cr}, \& \mathrm{Cd})$ using Atomic Absorption Spectrometer (Perkin Elmer absorption analyst 400 model).

Thereafter, the three composites were each immersed in the three different containers of the waste water and left for twenty four hours. The composites were removed and another portion of the waste water taken for analysis of the concentrations of the metals remaining in the water. The composites were immersed in the waters again and left for another twenty four hours before been removed and another portion of the waste water taken for the determination of the concentration of the metals remaining after the forty eight hour immersion of the composites.

\section{RESULTS AND DISCUSSION}

Properties of the waste water: The measured physico - chemical properties of the waste water were within the World Health Organisation(WHO) acceptable limit of $6.50-8.50\left(\mathrm{P}^{\mathrm{H}}\right) ; 1200$ ( Conductivity); 500(Total dissolved solid) ( Lohdip et al., 2012). These results obtained may be due to the fact that the Eatery started operations recently and the waste water gushing out from its premises has not built up a considerable level of these parameters. Some metal concentrations of the waste water were below while some were above the WHO and SON permissible limits. However, the essence of this investigation was not to assess the pollutant/ contaminant level of the waste water but to assess the sorption capacity of the prepared composite for the metals in the waste water.

Table 1: Physicochemical Parameters of the Waste Water

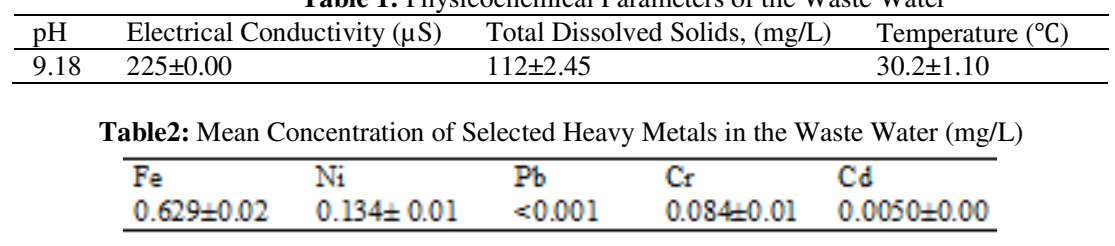

Table 3: Mean Concentration of Heavy metals absorbed after the $1^{\text {st }} 24$ hours $(\mathrm{mg} / \mathrm{L})$

\begin{tabular}{llllll}
\hline $\begin{array}{l}\text { Composites by Mass Ratio } \\
\text { HDPE: Saw dust: Egg Shell }\end{array}$ & $\mathbf{F e}$ & $\mathbf{N i}$ & $\mathbf{P b}$ & $\mathbf{C r}$ & $\mathbf{C d}$ \\
\hline $1.5: 1: 1.5$ & $0.146 \pm 0.01(23.2 \%)$ & $0.06 \pm 0.00(4.5 \%)$ & $<0.001$ & $0.075 \pm 0.01(89.3 \%)$ & $0.004 \pm 0.00(80.0 \%)$ \\
$2: 1.5: 0.5$ & $0.168 \pm 0.11(26.8 \%)$ & $0.072 \pm 0.01(53.7 \%)$ & $<0.001$ & $0.082 \pm 0.00(97.6 \%)$ & $0.001 \pm 0.00(20.0 \%)$ \\
$2: 1: 1$ & $0.061 \pm 0.01(9.7 \%)$ & $0.044 \pm 0.00(32.8 \%)$ & $<0.001$ & $0.071 \pm 0.00(84.5 \%)$ & $0.002 \pm 0.00(40.0 \%)$ \\
\hline \multicolumn{5}{c}{ HDPE: High density polyethylene; Saw Dust: Wood saw dust; Detection limit of the machine: 001mg/L }
\end{tabular}

Table 4: Concentration of Heavy metals absorbed after the 2nd 24hours (mg/L)

\begin{tabular}{llllll}
\hline $\begin{array}{l}\text { Composites by Mass Ratio } \\
\text { HDPE: Saw dust: Egg Shell }\end{array}$ & Fe & Ni & Pb & Cr & Cd \\
\hline $1.5: 1: 1.5$ & $0.126 \pm 0.01(20.0 \%)$ & $0.035 \pm 0.00(26.1 \%)$ & $<0.001$ & $0.008 \pm 0.00(9.5 \%)$ & $<0.001$ \\
$2: 1.5: 0.5$ & $0.135 \pm 0.02(21.5 \%)$ & $0.034 \pm 0.01(25.4 \%)$ & $<0.001$ & $<0.001$ & $<0.001$ \\
$2: 1: 1$ & $0.156 \pm 0.02(24.8 \%)$ & $0.017 \pm 0.00(12.7 \%)$ & $<0.001$ & $0.012 \pm 0.00(14.3 \%)$ & $<0.001$ \\
\hline
\end{tabular}

HDPE: High density polyethylene; Saw Dust: Wood saw dust; Detection limit of the machine: $001 \mathrm{mg} / \mathrm{L}$

Metal adsorption capacity of the Composites: The concentrations of the metals in the waste water were absolutely determined, not spiked. The order of variation of the concentration of the metals in the waste water is $\mathrm{Fe}>\mathrm{Ni}>\mathrm{Cr}>\mathrm{Cd}$. However, the percentage sorption by the three sorbents after twenty four hours indicates that chromium had the highest percentage sorption despite the fact its concentration in the waste water was low. This is contrary to the study of some workers who used different sorbents (Okure et al., 2010 and Okafor et al., 2013), whose results showed increased sorption at higher concentrations. This is perhaps due to the comparatively smaller size of chromium ion and the fact that the metal concentrations were not spiked. The $\mathrm{P}^{\mathrm{H}}$ of the waste water, 9.12 was alkaline enough to facilitate the sorption of the metal, as has been established by some workers (Okure et al., 2010 and Okafor et al., 2013). This might be due the same reason earlier adduced. Composite of 2:1.5:0.5 (HDPE: saw dust: egg shell) adsorbed the highest concentration of the metals $(0.168 \mathrm{mg} / \mathrm{L}, \mathrm{Fe}$; $0.072 \mathrm{mg} / \mathrm{L}, \mathrm{Ni}$ and $0.082 \mathrm{mg} / \mathrm{L}, \mathrm{Cr}$ than the other composites of 1.5: 1: 1.5 and 2:1:1 except $\mathrm{Cd}$. This 
suggests that the increased level of saw dust in the composite, 2:1.5:0.5 may have provided the increased pore sites which enhanced the adsorption of the metals. In the next 24 hours there was no systematic variation in the sorbed concentration of the metals and even the composition of the composite mix did not show any systematic variation in sorption capacity. This may have resulted from the blocking of most of the pore sites during the first 24 hours of sorption.

Conclusion: The composite mix, 2:1.5:0.5(HDPE: saw dust: egg shell) adsorbed the highest concentration of all the metals except cadmium. Chromium had the highest percentage sorption despite the fact that its concentration in the waste water was low, contrary to the result of some previous workers. After the $1^{\text {st }} 24$ hours, there was no systematic pattern of variation of the concentration of the adsorbed metals and the composite mix, which may be due to the blocking of some of the pore sites by the earlier adsorbates.

Acknowledgement: I sincerely appreciate the Technologists in the Department of Chemistry, Federal University of Petroleum Resources, Effurun who assisted me with some of the experimentals. I thank the Research Assistants who accompanied me in the collection of the waste samples.

\section{REFERENCE}

Dobrzanski, Z; Kalaeu, R; Gorecka, H ; Cholnaka, K (2005). The content of micro elements and trace elements in raw milk from cows in Silesian Region. Polish J. of Environ. Studies 14(5): 685-689.

Fernandez, LG ; Olalla, HY (2000). Toxicity and bioaccumulation of lead and cadmium in marine protozoan communities. Ecotoxicol. and Environ. Saf. 47: 266-267.

Gardea-Torresdey, JI; Peralta-Videa, JR; Rosa, GD; Parsons, JG (2005). Phytoremediation of heavy metals and study of the metal coordination. X-ray absorpt. Spectros. 297(17-18): 1797-1810.

Han, R; Zhang, J; Zou, W; Shi, J; Liu, H (2005). Equilibrium biosorption isotherm for lead ion on chaff. J. Hazard. Mater. 125:266

Israel, AU; Inam, E (2014). Removal of zinc from aqueous solution by adsorption using coconut coir dust. J. Chem. Soc. Nig. 39(1): 79-85.

Jern, W (2006). Industrial waste water treatment. Imperial College Press, Singapore, 150-155
Kumar, KV (2006). Removal of hazardous dye, tartrazine from aqueous solution using waste materials. J. Hazard. Mater. 136: 197.

Lohdip, YN; Gongden, JJ; Pam, KC (2012). Quality assessment of two surface dams in two communities of Plateau State, Central Nigeria. J. Chem. Soc. Nig. 38(1): 65- 69

McGrath, SP ; Smith, S (1990). Chromium and nickel in heavy metals in soils. (E. D. Blackie, \& B. J. Alloway, Eds.). Chapman and hall, Glasgow, UK, P. $25-150$

Ndiaye, D; Fanton, E; Morlat-Therias, S; Vidal, LT ; Gardette, J (2008). Durability of Wood Polymer Composites: Part 1. Influence of Wood on the Photochemical Properties. J. Compos. Sci. and tech. 68:2779-2784.

Nunez, AJ; Sturm, PC; Kenny, JM; Aranguren, MI; Marcovich, NE; Reboredo, MM (2003). Mechanical characterization of PP/wood flour composites. J. Appl. Sci. 88: 1420-1428.

Okafor, PC; Okon, PU; Daniel, EF; Ikeuba, AI; Ekpe, UJ (2013). Adsorption capacity of periwinkle (Tympanotonus Fuscatus) shell for Lead, Copper, Cadmium and Arsenic from aqueous solutions. $J$. Chem. Soc. Nig. 38(1):77-84.

Okure, IS; Okafor, PC; Ibok, UJ (2010). Adsorption of $\mathrm{Cu}^{+2}, \mathrm{As}^{+3}$ and $\mathrm{Cd}^{+2}$ ions from aqueous solution by eggshell. Glo. J. Pure and Appl. Sci. 16(4): 407

Saidi, M (2010). Experimental studies on effect of heavy metals presence in industrial wastewater on biological treatment. Int. J. Environ. Sci. 1(4): 666676.

Salem, HM; Eweida, EA; Farag, A(2000). Heavy metals in drinking water and their environmental impact on human health. J. Biores. Technol. 30:542- 556.

Srivastava, NK ; Majumder, CB (2008). Novel biofiltration methods for the treatment of heavy metals from industrial wastewater. $J$. Hazard Mate. 151: 1-8.

Sulak, MT; Demirbas, E; Kobya, M (2007). Removal of atrazon yellow from coloured waste water. $J$. Biores. Technol. 98: 2590- 2598. 